ORIginal PAPER

\title{
TC2 C776G POLYMORPHISM STUDIES IN PATIENTS With oral CANCER in The Polish population
}

\author{
Katarzyna Malinowska ${ }^{1}$, Alina Morawiec-Sztandera ${ }^{2}$, Ireneusz Majsterek ${ }^{1}$, \\ DARIUSZ KACZMARCZYK ${ }^{2}$
}

\begin{abstract}
${ }^{1}$ Department of Chemistry and Clinical Biochemistry, Medical University of Lodz, Poland ${ }^{2}$ Department of Head and Neck Neoplasms Surgery, Medical University of Lodz, Poland
\end{abstract}

\begin{abstract}
The first signs of oral cancer may resemble developing infections in the mucous membranes, with throat cancer symptoms being similar to those of upper respiratory tract infections. This greatly hinders rapid diagnosis and treatment. Better knowledge of the changes occurring in the metabolism of folic acid can help in understanding the carcinogenesis affecting DNA methylation and genome stability. Polymorphisms in genes encoding enzymes involved in this pathway may influence enzyme activity and thereby interfere with the concentrations of homocysteine and S-adenosylmethionine, which are important for DNA synthesis and cellular methylation reactions. The aim of the study was to determine the risk of oral cancer associated with the TC2 C776G polymorphism, as determined in 119 patients. Genotypes were determined by polymerase chain reaction-restriction fragment length polymorphism (PCR-RFLP). The test genotype was found to correspond to the Hardy-Weinberg (HW) equilibrium ( $\mathrm{p}>0.05$ ). In our population $\mathrm{G} / \mathrm{G}$ homozygosity of $\mathrm{C} 776 \mathrm{G}$ TC2 gene polymorphism increases the risk of oral cancer; OR (odds ratio): 4.3875; 95\% CI (confidence interval): 2.0518-9.319; $\mathrm{p}=0.001$. Regarding C/G genotype of the $\mathrm{C} 776 \mathrm{G}$ TC2 gene, polymorphism also increases the risk of developing this cancer; OR 2.4146 95\% CI: $1.2803-4.5541 ; \mathrm{p}=0.01$.
\end{abstract}

Key words: genetic polymorphism, TC2 gene, oral cavity cancer.

\section{Introduction}

Malignant tumors of the oral cavity constitute a diverse group of diseases which vary with regard to their location, construction and clinical course. The most common form of oral cancer is squamous cell carcinoma (OSCC), which accounts for more than $90 \%$ of all cancers and develops predominantly within the mobile (front) part of the tongue and floor of the mouth. Other kinds of carcinomas in this area are very rare. It is noted that adenocarcinomas of the oral cavity usually develop in the minor salivary glands distributed throughout the oral cavity. The Polish
National Cancer Registry (PNCR) reported that oral cancers are quite rare, with the total number of cases diagnosed each year in Poland being slightly higher than 1000. Data from 2010 show that annual survival of lip cancer is $91.6 \%$ in men and $91.3 \%$ in women, and tongue cancer survival is $54.9 \%$ in men and $74.9 \%$ in women. Men are 2 to 4 times more likely to be diagnosed with oral cancer than women. The most significant causes of cancer of the oral cavity are harmful carcinogens contained in tobacco smoke, although other factors, such as consumption of strong alcohol and poor oral hygiene, also have an impact. 
In recent years there has been a proliferation in the number of young patients (in their thirties) who have developed oral cancer, including women, who were neither smokers nor habitual drinkers of alcohol. In most European countries the number of men diagnosed with oral cancer is still greater than the number of women, in contrast to Asian countries, where the incidence of such tumors is the same in both groups $[1,2]$. According to medical literature and statistics, India is the country where most oral cancers occur, which is likely to be connected with overuse of tobacco products, especially chewing black tobacco. In the epidemiology of oral cancer, beside such risk factors as smoking cigarettes and alcohol abuse, inadequate oral hygiene, human papillomavirus (HPV) infection, riboflavin and iron deficiency also have a strong influence. The occurrence of oral cancer is five times more likely in smokers than non-smokers. In a study conducted in patients who abused alcohol we recorded a convergence between the occurrence of cancer and the impact of the risk factor, confirmed by the fact that alcohol products contain carcinogens $[5,6,7]$. In addition, mechanical irritation of the oral mucosa by poorly fitting or damaged dentures also increases the risk of cancer of the oral cavity. In the last few years there has been a surge of interest in the coincidence between genetic changes of some enzymes responsible for foliate transformations and metabolic transition. It was confirmed that in some oral cavity disorders there is involvement of genetic polymorphisms of enzymes reacting in mono-carbon group metabolism, especially transcobalamin II (TC2). TC2 is a $\beta 2$-globulin which belongs to the group of peptides transporting $\mathrm{B}_{12}$ vitamin in the blood and allowing it to enter the human cell. TC2 is a key factor essential for proper activity of methionine synthase enzyme, the function of which is the transformation of homocysteine into methionine. The most common polymorphism of the TC2 gene is substitution of cytosine for guanine at position 776, which was first described by Namour et al. in 1998. The substitution causes a change of proline arginine at position 259 of the peptide sequence of TC2 [8]. Folic acid is an essential nutrient that plays an important role in DNA synthesis and methylation [9, 10, 11]. Folate deficiency can reduce global DNA methylation, which is associated with genetic instability and the formation of tumors [12]. Low folate intake has been positively associated with the occurrence of colon [12], breast $[17,18,19,20]$, lung $[17,18,21,22]$, colorectal $[17,18,21,22]$, and head and neck cancer $[23]$. The presence of $\mathrm{C} 776 \mathrm{G}$ polymorphism of the TC2 gene in transcobalamin leads to substitution of the amino acid proline arginine at codon 259 (P259R) [24, 25]. Studies suggest that the presence of the $\mathrm{C} 776 \mathrm{G}$ polymorphism in the TC2 gene may affect the binding affinity of transcobalamin to cobalamin $(\mathrm{Cbl})$ and the ability to transport $\mathrm{Cbl}$ to tissues $[25,26]$. Although no studies have linked C776G TC2 gene polymorphism with the occurrence of oral cancer, Biselli [27] reports a relationship between the polymorphism and the risk of maternal Down syndrome, which is related to the etiology of abnormal folate metabolism. Afman et al. [25] found no association between the presence of C776 TC2 gene polymorphisms and the risk of neural tube defects. Folate, a vitamin of the B group involved in one-carbon group metabolism, plays an important role in DNA synthesis and methylation. Several polymorphisms in the genes involved in folate uptake and biotransformation have been shown to be associated with the risk of cancer and response to anticancer drugs. The aim of this study was to determine the relationship between the C776G polymorphism of the TC2 gene and the risk of oral cancer.

\section{Material and methods}

The study was conducted with the approval of the Local Ethics Committee of the Medical University of Lodz (RNN/142/09/KB ). For the study group, DNA was isolated from peripheral blood lymphocytes obtained from a group of 119 unrelated patients, 48 women and 71 men (mean age $48 \pm 13.50$ ), with oral cavity cancer which had been confirmed histologically. All patients were diagnosed and treated in the Department of Head and Neck Neoplasms Surgery Medical University of Lodz between 2008 and 2014. For a control, DNA was extracted from a group of 102 unrelated healthy volunteers: 43 women and 59 men (mean age $48 \pm 17.90$ ). Samples of peripheral blood ( $5 \mathrm{ml}$ in EDTA - ethylenediaminetetraacetic acid) were taken from the antecubital vein. Postoperative material consisted of cancerous tissues taken from the mouth. All patients and controls were matched for age and gender. RS- (RefSNP accession ID) for $\mathrm{C} 776 \mathrm{G}$ polymorphism of the gene TC2 is 1801198.

\section{Polymorphism analysis}

\section{TC2 C776G genotyping by PCR-RFLP}

DNA was extracted from peripheral blood lymphocytes using DNA Blood Mini Kits (A\&A Biotechnology, Gdynia, Poland). Genotypes were determined by polymerase chain reaction-restriction fragment length polymorphism (PCR-RFLP). PCR was carried out in a volume of $10 \mu \mathrm{l}$. The reaction mixture consisted of $100 \mathrm{ng}$ of genomic DNA, $0.5 \mu \mathrm{mol}$ of each primer and $3 \mathrm{U}$ of Taq polymerase. The PCR cycling conditions consisted of an initial denaturation step of $94^{\circ} \mathrm{C}$ for 10 minutes, followed by 34 cycles of $94^{\circ} \mathrm{C}$ for 1 minute, $56^{\circ} \mathrm{C}$ for $45 \mathrm{~s}, 72^{\circ} \mathrm{C}$ for $45 \mathrm{~s}$ and final extension of $72^{\circ} \mathrm{C}$ for 10 minutes. 
Table I. Primers, length of PCR products and restriction enzymes

\begin{tabular}{cccc}
\hline Polymorphism & Primers & $\begin{array}{c}\text { Product } \\
\text { Length }\end{array}$ & $\begin{array}{c}\text { Restriction } \\
\text { ENZYMe }\end{array}$ \\
\hline TC2C776G & Sense 5'-CAT CAG AAC AGT GCG AGA GG-3' & 300 bp & ScrFI \\
& Antisense 5'-GTG CCA GACAGT CTG GGA AG-3' & & $\left(37^{\circ} \mathrm{C}\right)$ \\
\hline
\end{tabular}

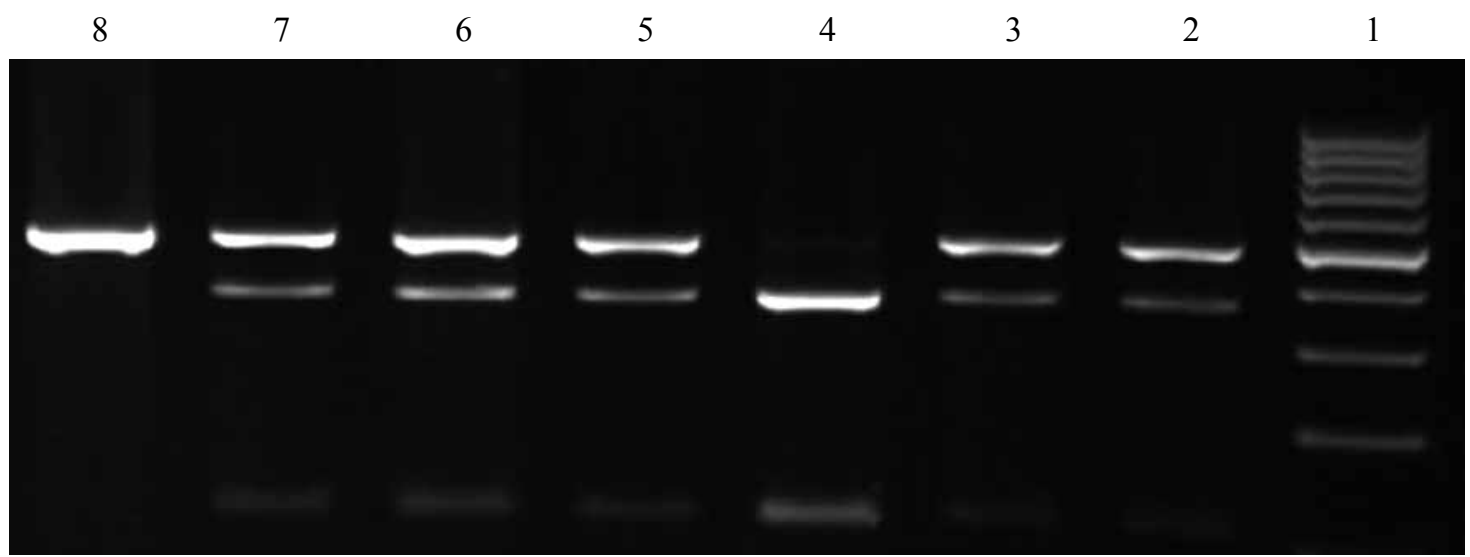

Fig. 1. Analysis of genotype polymorphism 766C> G gene TC2 after hydrolysis with restriction enzyme SCRFI (rs 1801198). Track 1 marker tracks 2, 3, 5, 6, 7, heterozygous CG, lane 4, homozygous CC, lane 8 is homozygous GG. Obtained fragments of 201 and 99 bp for wild-type genotype type 766CC (two bands), and for heterozygotes 766CG three bands corresponding to fragments of 300, 201 and 99 bp. 766GG mutant genotype one band corresponding to a fragment of $300 \mathrm{bp}$

A $10 \mu \mathrm{l}$ amount of specifically positive PCR products was digested overnight with $1 \mu \mathrm{l}$ of $\operatorname{ScrFI}$ (New England Bio Labs, Beverly, MA) at $37^{\circ} \mathrm{C}$, and the digested DNA fragments were resolved on $3 \%$ agarose gel. The randomly selected DNA samples amplified by PCR for each genotype were cross-checked by DNA sequencing, and the results were found to be $100 \%$ concordant [27]. The primers, length of PCR products and restriction enzymes are summarized in Table I. Genotypes were designated as follows: $99 \mathrm{bp}$ and $201 \mathrm{bp}$ for $\mathrm{C} / \mathrm{C}$; 99, 201 and $300 \mathrm{bp}$ for C/G; and $300 \mathrm{bp}$ for $\mathrm{G} / \mathrm{G}$. Figure 1 presents a representative electropherogram obtained after digestion of PCR products.

\section{Statistical analysis}

The frequency of the analyzed polymorphisms among CRC patients and controls was evaluated using the Hardy-Weinberg (HW) equilibrium test. The odds ratios (OR) and $95 \%$ confidence intervals (95\% $\mathrm{CI})$ were adjusted for age and gender. Means were compared using the t-test or analysis of variance. The distribution of the alleles was analyzed with Yates' $\chi^{2}$ test according to age, gender, tumor location, grading, nodal involvement, distant metastases and recurrence. P-values were calculated as two-sided. Probabilities were considered significant at $\mathrm{p}$-values less than 0.05 .

\section{Results}

In a total of 119 unrelated patients, 48 women and 71 men (mean age 48), oral cavity cancer was histologically confirmed. Stage T1 was confirmed in $56(47.1 \%)$ patients, T2 in $46(38.7 \%)$, T3 in 12 $(10 \%)$ and $\mathrm{T} 4$ in $5(4.2 \%)$. In 28 patients $(23.5 \%)$ nodal metastases were observed.

The distribution of the TC2 C776G polymorphism in patients $(\mathrm{X} 2=0.4671 ; \mathrm{p}=0.4942)$ and the control group (X2 $=1.6034 ; \mathrm{p}=0.2054$ ) was found to correspond to the Hardy-Weinberg prediction. The TC2 C776G genotype was found to be $\mathrm{C} / \mathrm{C}$ in $25(21.00 \%), \mathrm{C} / \mathrm{G}$ in $55(46.20 \%)$ and $\mathrm{G} / \mathrm{G}$ in $39(33.00 \%)$ patients with cancer of the oral cavity, while in control subjects $\mathrm{C} / \mathrm{C}$ was found in $45(44.10 \%), C / G$ in $41(40.20 \%)$ and $G / G$ in 16 (15.70\%) patients. Two genotypes were associated with an increased risk of sporadic cancer compared with controls: C/G (OR: 2.4146; 95\% CI: 1.2803$4.5541 ; \mathrm{p}=0.01)$ and $\mathrm{G} / \mathrm{G}(\mathrm{OR}: 4.3875 ; 95 \% \mathrm{CI}$ : 2.0518-9.319; $\mathrm{p}=0.001)$. A more detailed distribution of genotypes and alleles for the case and control groups is given in Table II.

Table III contains data showing a lack of correlation between genotype, sex, smoking and alcohol use.

We analyzed the distribution of the TC2 C776G genotype in the largest group of cancers, i.e. C00, $\mathrm{C} 02$ and $\mathrm{C} 04$. 
Table II. Genotype and allele frequencies for TC2 C776G in oral cancer in patients and control subjects from the Polish population

\begin{tabular}{|c|c|c|c|c|}
\hline Genotype/Allele & $\begin{array}{c}\text { Control Subjects } \\
\text { No }(\%)\end{array}$ & $\begin{array}{l}\text { PATIENTS, NO. }(\%) \\
\text { *ICD } 10\end{array}$ & OR $(95 \% \mathrm{CI})$ & P-VALUe \\
\hline Total & & & - & - \\
\hline TC2 C776G & $102(100)$ & $119(100)$ & & \\
\hline \multirow[t]{7}{*}{ genotypes } & & C00-20 (16.81) & & \\
\hline & & $\mathrm{CO} 1-4(3.36)$ & & \\
\hline & & CO2-54 (45.38) & & \\
\hline & & $\mathrm{CO} 3-5(4.20)$ & & \\
\hline & & C04-30 (25.21) & & \\
\hline & & $\cos -4(3.36)$ & & \\
\hline & & C06-2 (1.68) & & \\
\hline \multirow[t]{8}{*}{$\mathrm{C} / \mathrm{C}$} & $45(44.10)$ & $25(21.00)$ & Ref. & \\
\hline & & C00-4/20 (20.00) & & \\
\hline & & $\mathrm{C} 01-1 / 4(25.00)$ & & \\
\hline & & C02-11/54 (20.37) & & \\
\hline & & C03-1/5 (20.00) & & \\
\hline & & C04-6/30 (20.00) & & \\
\hline & & C05-1/4 (25.00) & & \\
\hline & & C06-1/2 (50.00) & & \\
\hline \multirow[t]{8}{*}{$\mathrm{C} / \mathrm{G}$} & $41(40.20)$ & $55(46.20)$ & $2.4146(1.2803-4.5541)$ & 0.01 \\
\hline & & C00-9/20 (45.00) & & \\
\hline & & $\mathrm{C} 01-3 / 4(75.00)$ & & \\
\hline & & $\mathrm{C} 02-24 / 54(44.44)$ & & \\
\hline & & $\mathrm{C} 03-2 / 5(40.00)$ & & \\
\hline & & C04-15/30 (50.00) & & \\
\hline & & C05-1/4 (20.00) & & \\
\hline & & C06-1/2 (50.00) & & \\
\hline \multirow[t]{8}{*}{$\mathrm{G} / \mathrm{G}$} & $16(15.70)$ & $39(33.00)$ & $4.3875(2.0518-9.319)$ & 0.001 \\
\hline & & $\mathrm{C} 00-7 / 20(35.00)$ & & \\
\hline & & $\mathrm{C} 01-0 / 4(0.00)$ & & \\
\hline & & C02-19/54 (35.18) & & \\
\hline & & $\mathrm{C} 03-2 / 5(40.00)$ & & \\
\hline & & C04-9/30 (30.00) & & \\
\hline & & C05-2/4 (50.00) & & \\
\hline & & $\mathrm{C} 06-0 / 2(0.00)$ & & \\
\hline $\mathrm{C}$ & $131(56.96)$ & $105(44.12)$ & Ref. & \\
\hline G & $99(43.04)$ & $133(55.88)$ & $1.6761(1.1629-2.4157)$ & 0.005 \\
\hline
\end{tabular}

*COO - malignant neoplasm of the lip; CO1 - malignant neoplasm of base of tongue; CO2 - malignant neoplasm of other and unspecified part of tongue; CO3 - malignant neoplasm of gum; CO4-malignant neoplasms of floor of mouth; CO5 - malignant neoplasm of palate; CO6 - malignant neoplasms of other and unspecified part of floor of mouth 
The TC2 $\mathrm{C} 776 \mathrm{G}$ genotype was found to be $\mathrm{C} / \mathrm{C}$ in $4(20 \%), \mathrm{C} / \mathrm{G}$ in $9(45 \%)$ and $\mathrm{G} / \mathrm{G}$ in $7(35 \%)$ patients with cancer of the lip (C00). In patients with tongue cancer $(\mathrm{C} 02)$ the $T C 2 \mathrm{C} 776 \mathrm{G}$ genotype was found to be $\mathrm{C} / \mathrm{C}$ in $6(11.1 \%), \mathrm{C} / \mathrm{G}$ in $23(42.6 \%)$ and $\mathrm{G} / \mathrm{G}$ in $25(46.3 \%)$. In patients with floor of the month cancer (C04) the TC2 $\mathrm{C} 776 \mathrm{G}$ genotype was found to be $\mathrm{C} / \mathrm{C}$ in $4(13.3 \%), \mathrm{C} / \mathrm{G}$ in $9(30 \%)$ and $\mathrm{G} / \mathrm{G}$ in $17(66.7 \%)$.

\section{Discussion}

Oral cavity cancer is characterized by rapid development, and clinical malignancy and lymph node metastatic tumors occur in about $40 \%$ of patients with oral cancer [28]. $80 \%$ of cases of oral cancer are curable. Precancerous lesions should be removed and treatedw in smokers or those infected with HPV 16 and 18. Although one quarter of patients are too young to smoke and drink alcohol, the number of these patients is increasing rapidly. The risk of developing oral cancer is seven times higher in smokers and six times higher in alcohol abusers [29, 30, 31]. In those who give up smoking, the risk of cancer decreases with time, whereas the risk increases with the number of cigarettes smoked per day.

Dietary factors may play a role, together with genetic predisposition, because not all smokers or alcoholics get cancer, and not all patients with cancer have such habits [32, 33]. Other factors are associated with the ability to metabolize carcinogens or repair DNA. Individual susceptibility to cancer may be associated with a particular genotype, which might in turn be associated with metabolic disorders, resulting in increased exposure to carcinogens [34], the most important being aromatic amines. To summarize, oral cancer is known to be associated with smoking and chewing tobacco, the consumption of alcoholic beverages, a diet low in fresh fruits and vegetables, poor oral hygiene and ill-fitting dentures, and, in the case of cancer of the lips, exposure to sunlight [35]. Water-soluble vitamins, such as $\mathrm{B}$ vitamins $\left(B_{1}, B_{2}, B_{3}, B_{6}, B_{12}\right)$ folic acid and vitamin $C$, cannot be stored by the body and are rapidly excreted $[26,35]$. One essential nutrient is cobalamin, which plays an important role as a coenzyme in the conversion of L-methylmalonyl-CoA, succinyl-CoA and the remethylation of homocysteine to methionine. HPV infection (the most common HPV16) can also cause some forms of cancer, and patients with oral cavity cancer associated with HPV infection are younger and often do not use alcohol and cigarettes.

Although no connection has been found previously between the occurrence of polymorphism TC2 C776G and the risk of cancer of the oral cavity, it has been found to be related to the occurrence of other disease entities. For example, the TC2 C7776G poly-
Table III. Odds ratio of head and neck cancer related to TC2 genotypes by gender, tobacco and alcohol consumption in patients

\begin{tabular}{ccc}
\hline Risk faCtor & $\begin{array}{c}\text { OR }(95 \% \text { CI) } \\
\text { TC2 C776G* }\end{array}$ & P-VAlue \\
\hline $\begin{array}{c}\text { Tobacco con- } \\
\text { sumption } \\
\text { Yes }\end{array}$ & $\begin{array}{c}1.5517(0.6158-3.9103) \\
\text { No }\end{array}$ & 0.351 \\
Alcohol con- & $3.31788(0.4296-$ & 0.764 \\
sumption & $1.7193(0.5573-5.3045)$ & 0.342 \\
Yes & $2.0263(0.5935-6.9178)$ & 0.254 \\
No & & \\
\hline Gender & & \\
Male & $0.7219(0.275-1.8954)$ & 0.507 \\
Female & $0.83(0.2984-2.309)$ & 0.719 \\
\hline TC2 C776G Reference: CC wild type genotype &
\end{tabular}

morphism has been associated with a higher risk of developing colorectal adenoma [35]. In addition, the $776 \mathrm{G}$ allele has been associated with the presence of colorectal neoplasia [36].

Our results indicate that the CG and GG genotypes and the $G$ allele have the effect of increasing the likelihood of oral cancer. However, further research of gene interactions in the metabolism of folic acid and studies using different populations are needed to examine polymorphisms and risk of cancer.

In conclusion, the present study suggests that the presence of TC2 $\mathrm{C} 776 \mathrm{G}$ is associated with increased risk of oral cancer. Genotypes $\mathrm{C} / \mathrm{G}$ and $\mathrm{G} / \mathrm{G}$, and the $776 \mathrm{G}$ allele, increase the risk of cancer.

The authors declare no conflict of interest.

\section{References}

1. Parkin DM, Bray F, Ferlay J, et al. Global cancer statistics, 2002. CA Cancer J Clin 2005; 55: 74-108.

2. Ferlay J, Shin RH, Bray F, et al. Estimates of worldwide burden of cancer in 2008: Globocan 2008. Int J Cancer 2008; 127 : 2893-2917.

3. Olivieri EHR, da Silva SD, Mendonc'a FF, et al. CYP1A2*1C,CYP2E1*5B, and GSTM1 polymorphisms are predictors of risk and poor outcome in head and neck squamous cell carcinoma patients. Oral Oncol 2009; 45: 73-79.

4. Wang Y, Guo W, He Y, et al. Association of MTHFR C677T and SHMT1 C1420T with susceptibility to ESCC and GCA in a high incident region of Northern China. Cancer Causes Control 2007; 18: 143-152.

5. Ragin CC, Modugno F, Gollin SM. The epidemiology and risk factors of head and neck cancer: a focus on human papillomavirus. J Dental Research 2007; 86: 104-114.

6. Argiris A, Karamouzis VM, Raben D. Head and neck cancer. Lancet 2008; 371: 1695-1709. 
7. Blount BC, Mack MM, Wehr CM, et al. Folate deficiency causes uracil misincorporation into human DNA and chromosome breakage: implications for cancer and neuronal damage. Proc Natl Acad Sci U S A 1997; 94: 3290-3295.

8. Namour F, Guy M, Aimone-Gastin I, et al. Isoelectrofocusing phenotype and relative concentration of transcobalamin II isoproteins related to the codon $259 \mathrm{Arg} /$ Pro polymorphism. Biochem Biophys Res Commun 1998; 251: 769-774.

9. Wang Y, Guo W, He Y, Chen Z, Wen D, et al. Association of MTHFR C677T and SHMT1 C1420T with susceptibility to ESCC and GCA in a high incident region of Northern China. Cancer Causes Control 2007; 18: 143-152.

10. Wang L, Lu J, An J, et al. Polymorphisms of cytosolic serine hydroxyl-methyltransferase and risk of lung cancer: a case-control analysis. Lung Cancer 2007; 57: 143-151.

11. Ma E, Iwasaki M, Junko I, et al. Dietary intake of folate, vitamin B6, and vitamin B12, genetic polymorphism of related enzymes, and risk of breast cancer: a case-control study in Brazilian women. BMC Cancer 2009; 9: 122.

12. Linhart HG, Troen A, Bell GW, et al. Folate deficiency induces genomic uracil misincorporation and hypomethylation but does not increase DNA point mutations. Gastroenterology 2009; 136: 227-235.

13. Garcia-Crespo D, Knock E, Jabado N, et al. Intestinal neoplasia induced by low dietary folate is associated with altered tumor expression profiles and decreased apoptosis in mouse normal intestine. J Nutr 2009; 139: 488-494.

14. Langevin SM, Lin D, Matsuo K, et al. Review and pooled analysis of studies on MTHFR C677T polymorphism and esophageal cancer. Toxicol Lett 2009; 184: 73-80.

15. Kane MA. The role of folates in squamous cell carcinoma of the head and neck. Cancer Detect Prev 2005; 29: 46-53.

16. Kim DH. The interactive effect of methyl-group diet and polymorphism of methylenetetrahydrofolate reductase on the risk of colorectal cancer. Mutat Res 2007; 622: 14-18.

17. Kim Y. Folate and carcinogenesis: evidence, mechanisms, and implications. J Nutr Biochem 1997; 10: 66-88.

18. Mason JB, Choi SW. Effects of alcohol on folate metabolism: implications for carcinogenesis. Alcohol 2005; 35: 235-241.

19. Xu X, Gammon MD, Wetmur JG, et al. B-vitamin intake, onecarbon metabolism, and survival in a population based study of women with breast cancer. Cancer Epidemiol Biomarkers Prev 2008; 8: 2109-2116.

20. Kalmbach RD, Choumenkovitch SF, Troen AP, et al. A 19-base pair deletion polymorphism in dihydrofolate reductase is associated with increased unmetabolized folic acid in plasma and decreased red blood cell folate. J Nutr 2008; 138: 2323-2327.

21. Stolzenberg-Solomon RZ, Chang SC, Leitzmann MF, et al. Folate intake, alcohol use, and postmenopausal breast cancer risk in the prostate, lung, colorectal, and ovarian cancer screening trial. Am J Clin Nutr 2006; 83: 895-904.

22. Xu X, Gammon MD, Zeisel SH, et al. Choline metabolism and risk of breast cancer in a populationbased study. FASEB J 2008; 22: 2045-2052.

23. Hsiung DT, Marsit CJ, Houseman EA, et al. Global DNA methylation levelin whole blood as a biomarker in head and neck squamous cellcarcinoma. Cancer Epidemiol Biomarkers Prev 2006; 16: 108-114.

24. Charasson V, Hillaire-Buys D, Solassol I, et al. Involvement of gene polymorphisms of the folate pathway enzymes in gene expression and anticancer drug sensitivity using the NCI-60 panel as a model. Eur J Cancer 2009; 45: 2391-2401.

25. Afman LA, Lievers KJ, Van der Put NM, et al. Single nucleotide polymorphisms in the transcobalamin gene: relationship with transcobalamin concentrations and risk for neural tube defects. Eur J Hum Genet 2002; 10: 433-438.
26. Miller JW, Ramos MI, Garrod N, et al. Transcobalamin II $775 \mathrm{GNC}$ polymorphism and indices of vitamin B12 status in healthy older adults. Blood 2002; 15: 718-720.

27. Biselli JM, Brumati D, Frigeri VF, et al. A80G polymorphism of reduced folate carrier 1 (RFC1) and $\mathrm{C} 776 \mathrm{G}$ polymorphism of transcobalamin 2 (TC2) genes in Down's syndrome etiology. Med J 2008; 126: 329-332.

28. Noguti J, De Moura CF, De Jesus GP, et al. Metastasis from oral cancer: an overview. Cancer Genomics Proteomics 2012; 9: 329-335.

29. da Silva LM, Galbiatti AL, Ruiz M, et al. MTHFD1 G1958A, BHMT G742A, TC2 C776G and TC2 A67G polymorphisms and head and neck squamous cell carcinoma risk. Mol Biol Rep 2012; 39: 887-893.

30. Omar E. Current concepts and future of noninvasive procedures for diagnosing oral squamous cell carcinoma - a systematic review. Head Face Med 2015; 11: 6. doi: 10.1186/ s13005-015-0063.

31. Dolan RW, Vaughan CW, Fuleihan N. Symptoms in early head and neck cancer: an inadequate indicator. Otolaryngol Head Neck Surg 1998; 119: 463-467.

32. Wang X, Xu J, Wang L, et al. The role of cigarette smoking and alcohol consumption in the differentiation of oral squamous cell carcinoma for the males in China. J Cancer Res Ther 2015; 11: 141-145.

33. Mahapatra S, Kamath R, Shetty BK, et al. Risk of oral cancer associated with gutka and other tobacco products: A hospital-based case-control study. J Cancer Res Ther 2015; 11: 199-203.

34. Zhang Y, Wang R, Miao L, et al. Different levels in alcohol and tobacco consumption in head and neck cancer patients from 1957 to 2013. PLoS One 2015; 10: 0124045.

35. Hazra A, Wu K, Kraft P, et al. Twenty-four non-synonymous polymorphisms in the one-carbon metabolic pathway and risk of colorectal adenoma in the Nurses' Health Study. Carcinogenesis 2007; 28: 1510-1519.

36. Curtin K, Slattery M, Ulrich CM, et al. Genetic polymorphisms in one-carbon metabolism: associations with $\mathrm{CpG}$ island methylator phenotype (CIMP) in colon cancer and the modifying effects of diet. Carcinogenesis 2007; 28: 1672-1679.

\section{Address for correspondence}

\section{Katarzyna Malinowska}

Department of Chemistry and Clinical Biochemistry

Medical University of Lodz

Hallera 1 square

90-647 Lodz, Poland

e-mail:modmal@wp.pl 